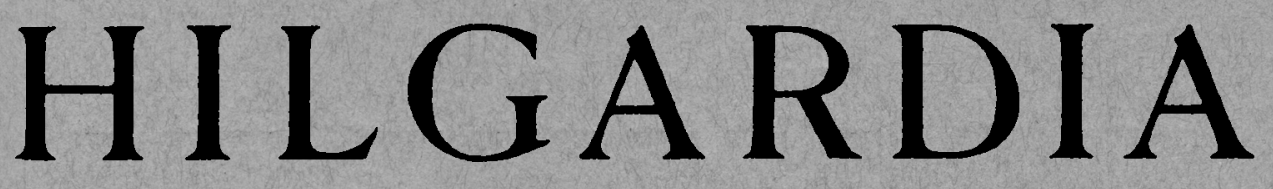

A Journal of Agricultural Science Publisbed by the California Agricultural Experiment Station

\title{
MECHANICAL PROPERTIES OF CALIFORNIA-GROWN MONTEREY PINE
}

\author{
ROBERT A. COCKRELL
}


Monterey pine has proved to be one of the best softwood species for lumber production in Australia, New Zealand, and South Africa, but has long been regarded as a poor quality timber tree in California.

Tests of several basic mechanical and physical properties were made on six California-grown Monterey pine trees. The results show that native Monterey pine compares favorably with both United States softwoods and Australian-grown Monterey pine. It is an excellent construction wood, and should be considered for forest plantations in the milder areas of California. 


\section{H I L G A R D I A}

A Journal of Agricultural Science Published by

the California Agricultural Experiment Station

VoL. 28

JANUARY, 1959

No. 8

\section{MECHANICAL PROPERTIES OF CALIFORNIA-GROWN MONTEREY PINE ${ }^{1}$}

\section{ROBERT A. COCKRELL}

Monterey pine (Pinus radiata D. Don.) has become a softwood timber species of primary importance in many parts of the world. Because of its limited distribution and relatively small volume within its native range, however, it has not been well known nor highly regarded as a timber supplying species in California. One of the most rapid-growing California conifers, Monterey pine is well adapted to the coastal climate, and appears to flourish in a variety of soil types. It therefore seemed worthwhile to determine the mechanical properties of native-grown wood in order to assess its potentialities as a useful timber species in this state.

\section{MATERIALS AND METHODS}

Wood for testing was obtained from six trees. Four of them were growing in the center of the main stand of the species located on the Del Monte Properties between Monterey and Carmel. All four were dominant, mature trees in the forest, with relatively full, flat-topped crowns. They ranged in age from 50 to 75 years, and were 92 to 110 feet tall. The other two trees were growing in a plantation in Round Top Regional Park, just east of the city of Oakland, at an elevation of about 1,700 feet. All trees were cut separately and at long enough intervals to permit prompt testing of the green specimens. General information on the specimens used in the study is given in table 1.

The logs were cut from the trees in accordance with the general procedure described in American Society for Testing Materials Designation D143-49. Four logs between $81 / 2$ and 9 feet long were obtained from tree number 4 , from the Monterey Peninsula; one such $\log 8$ to 12 feet above the stump was obtained from each of the other five. In each case the log was cut so that a node was approximately in the center. Since the internodes were about $31 / 2$ feet long, this provided a maximum of clear, knot-free wood in each half (4-foot portion) of the log (fig. 1).

Test specimen blanks were prepared from the logs by following closely the procedure set forth in A.S.T.M. Designation D143-49. The $21 / 2 \times 21 / 2$-inch test blanks were assembled into two composite bolts from each log. One bolt was tested immediately in the green condition; the other was carefully

${ }^{1}$ Received for publication June 26, 1958.

2 Professor of Forestry and Associate Forester in the Experiment Station, Berkeley. 
stacked under a shed roof to air-dry. All of the green material was tested within a couple of weeks following the cutting of the tree. During that period, the green specimens were wrapped in damp cloths tightly covered with waterproof paper to prevent surface drying, and stored in a refrigerated room at $34^{\circ} \mathrm{F}$.

All mechanical testing, specific gravity determination, and shrinkage measurements conformed for the most part to the aforementioned A.S.T.M. standard. The following deviations should be noted, however. The stressstrain curves, from which the values for stress at proportional limits in compression parallel to grain were obtained, were based on the deflection over the full 8 -inch length of the specimens rather than the 6-inch length

TABLE 1

AGE AND SIZE OF CALIFORNIA-GROWN MONTEREY PINE TREES AND LOCATION OF TEST LOGS IN TREES

\begin{tabular}{|c|c|c|c|c|c|}
\hline \multirow{2}{*}{ Tree no. } & \multirow{2}{*}{$\begin{array}{c}\text { Approx. } \\
\text { age }\end{array}$} & \multirow{2}{*}{ D.B.H.* } & \multirow{2}{*}{$\begin{array}{l}\text { Total } \\
\text { height }\end{array}$} & \multicolumn{2}{|c|}{ Log location } \\
\hline & & & & $\begin{array}{l}\text { Height, } \\
\text { large end }\end{array}$ & $\begin{array}{l}\text { Height, } \\
\text { small end }\end{array}$ \\
\hline & years & inches & feet & feet & feet \\
\hline 1.. &..$\dagger$ & 28.3 & $\ldots \dagger$ & 10.0 & 19.0 \\
\hline 2. & 50 & 29.4 & 101 & 14.0 & 22.5 \\
\hline 3. & 77 & 30.3 & 110 & 8.0 & 17.0 \\
\hline \multirow[t]{4}{*}{4.} & 76 & 26.2 & 92 & 2.0 & 11.0 \\
\hline & & & & 11.0 & 20.5 \\
\hline & & & & 33.5 & 42.0 \\
\hline & & & & 58.0 & 66.5 \\
\hline 5 . & 43 & 28.7 & $76 \ddagger$ & 12.4 & 21.0 \\
\hline 6. & 43 & 24.5 & 69 & 13.7 & 22.2 \\
\hline
\end{tabular}

\footnotetext{
* Diameter outside bark at 4.5 feet above ground.

† Tree number 1 was cut by California State Division of Forestry personnel subsequent to selection by author. Age and height data were not obtained.

$\ddagger$ Top broken out.
}

prescribed. The specific gravity values, based on oven-dry weight and volume at 12 per cent moisture content, were determined by using volume calculated from the dimensions of the specimen rather than by immersion. The specific gravity based on green volume, however, was determined on the basis of volume calculated by immersion in water as prescribed.

\section{RESULTS AND DISCUSSION}

Basic data for the various mechanical and physical properties of the green wood are listed in table 2 , and for the dry wood, in table 3.

Moisture content of the green wood averaged about 35 per cent for the heartwood and 125 per cent for the sapwood. The latter showed the widest fluctuation, the rather dense tree number 3 having around 90 per cent, whereas the two lighter plantation trees, numbers 5 and 6 , had 145 per cent. The dry wood was tested at approximately 12 per cent moisture content, the actual values fluctuating between 10 and 14 per cent. Adjustment to 12 per cent was made with the U. S. Forest Products Laboratory exponential formula $(1939)^{3}$ using the intersection point 28.5 per cent employed by

\footnotetext{
${ }^{3}$ See "Literature Cited" for citations referred to in the text by author and date.
} 

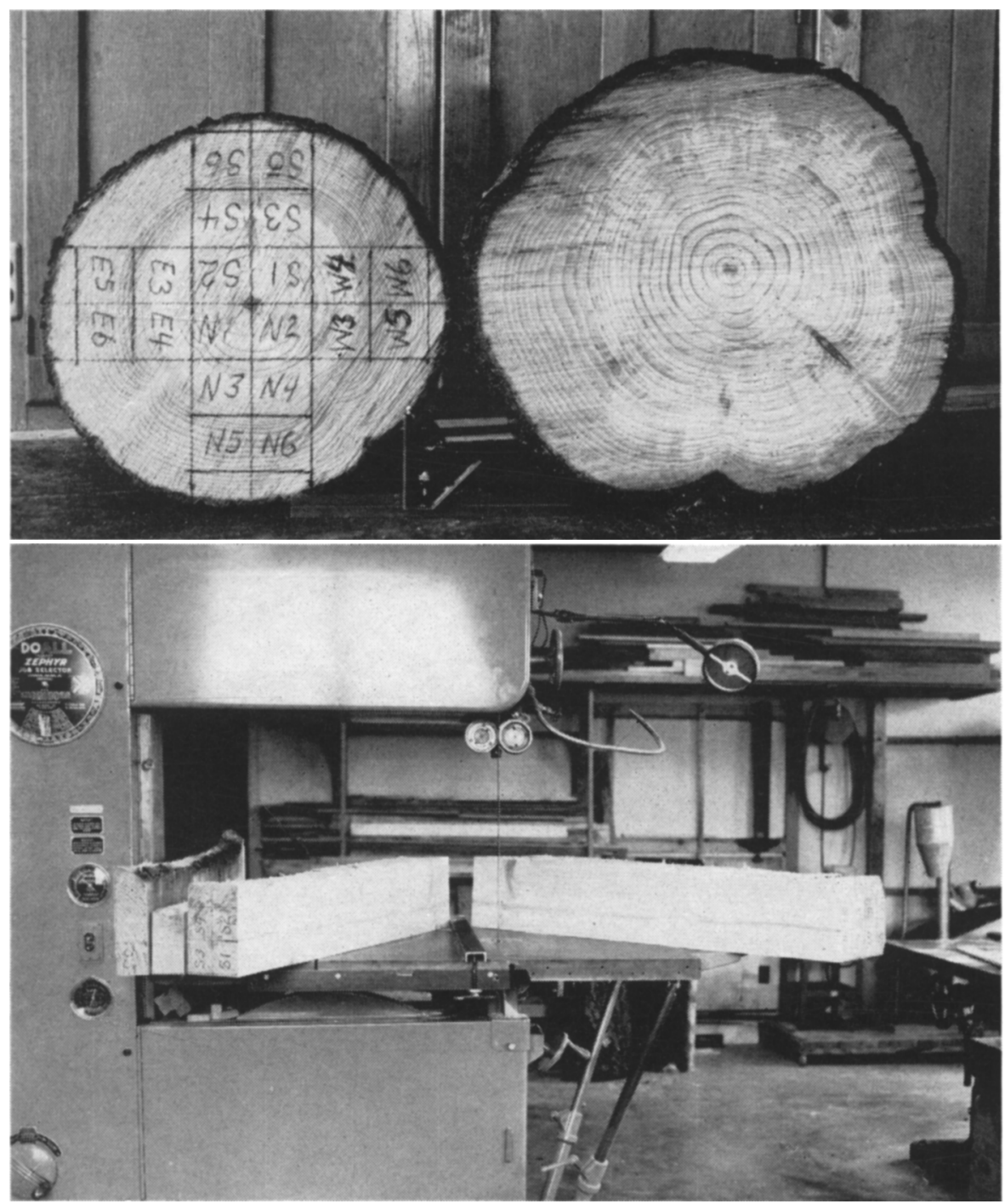

Fig. 1. Preparation of test specimens. Above: typical cross-sections of test logs. The log at left is marked for cutting. Below: test blanks $2 \frac{1}{2} \times 2 \frac{1}{2}$ inches, being prepared according to A.S.T.M. procedure. 


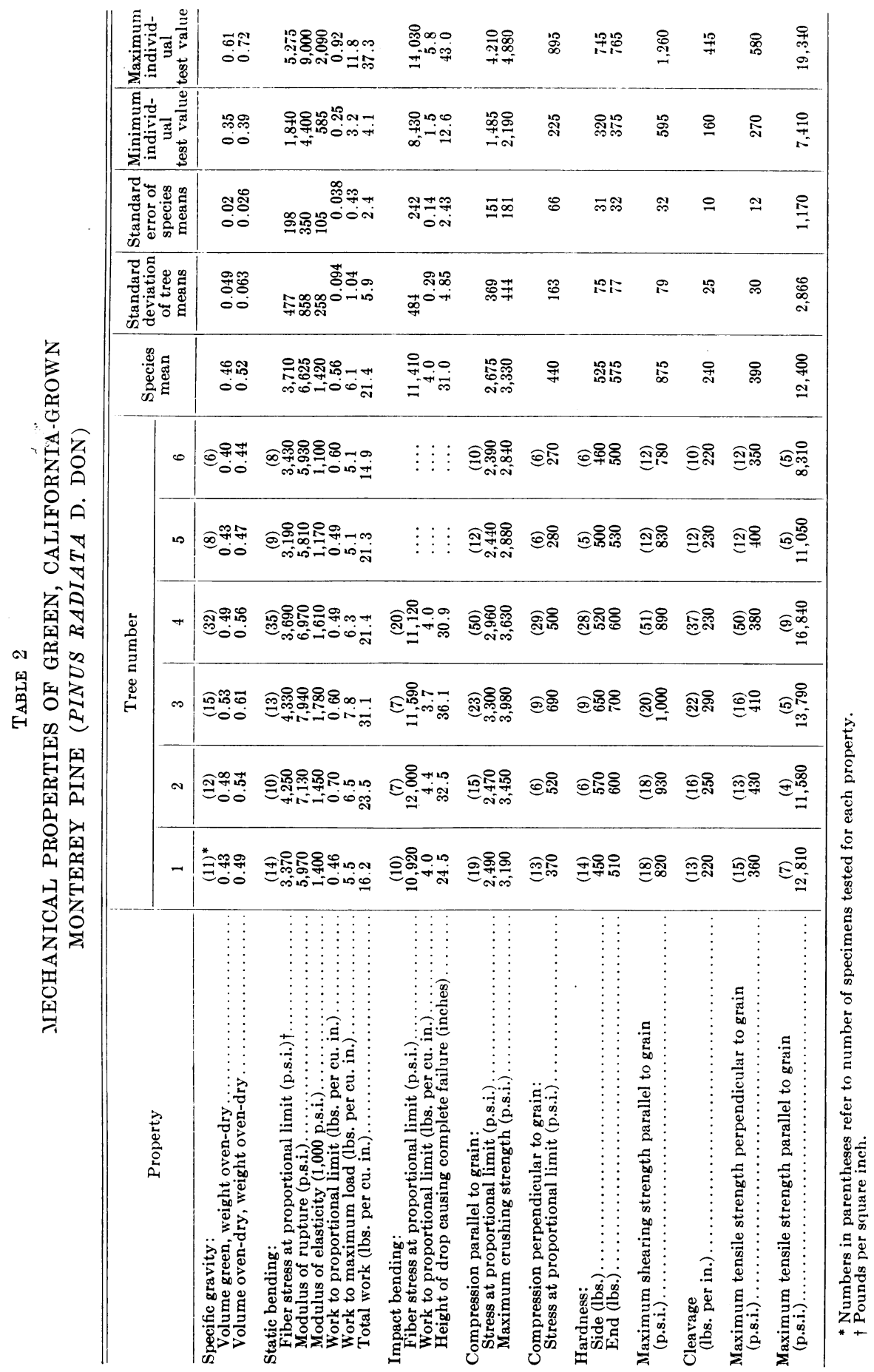




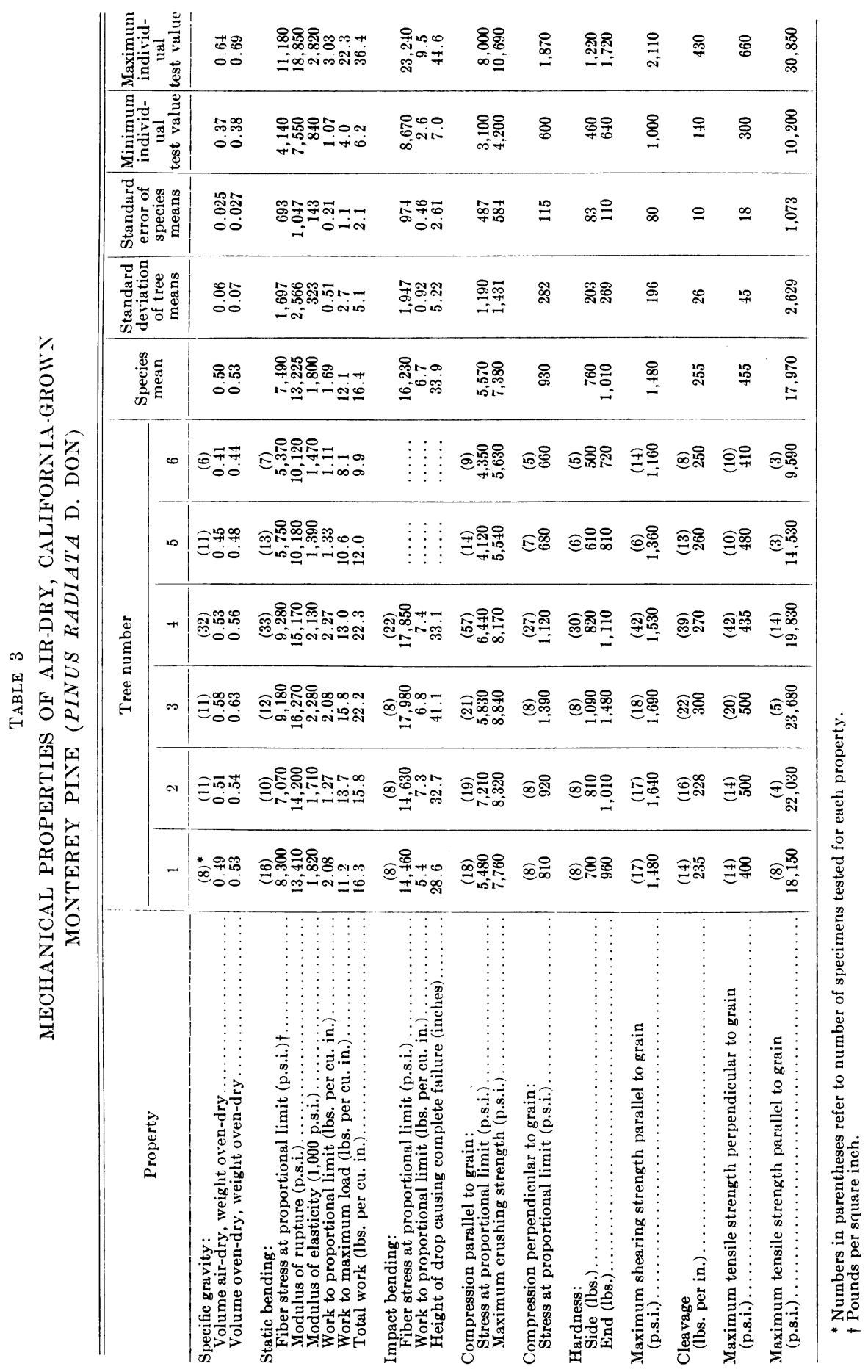


Langlands in his study (1937). Actually, specimens from trees numbered 3, 5 , and 6 were exactly 12 per cent when tested; trees 1 and 2 , slightly above 12 per cent; and tree 4, slightly below. Since the number of tests made varied from tree to tree, the species mean was calculated from the tree means, rather than from the individual test values, so that each tree had equal weight. In this regard also, the writer was influenced by the statement made by Langlands (1937) that use of tree means in calculating the species mean gives a closer estimate of the true species mean than does use of individual tests.

Growth Rate. The growth rate of the material tested, as reflected by the number of rings per inch of radius, is indicated in table 4 . These data are tabulated by test blank numbers, and are thus related to distance from the pith. Blanks 1 and 2 are immediately adjacent to the pith, and blanks 7 and 8 just under the bark. The data show that all the trees except number 1

TABLE 4

AVERAGE AND RANGE OF RINGS PER INCH FOR TREES TESTED

\begin{tabular}{|c|c|c|c|c|c|c|c|c|c|}
\hline \multirow{2}{*}{ Test blank nos.* } & \multirow{2}{*}{ Tree 1} & \multirow{2}{*}{ Tree 2} & \multirow{2}{*}{ Tree 3} & \multicolumn{4}{|c|}{ Tree 4} & \multirow{2}{*}{ Tree 5} & \multirow{2}{*}{ Tree 6} \\
\hline & & & & $\log 1$ & $\log 2$ & $\log 3$ & $\log 4$ & & \\
\hline 1 and 2. & $\begin{array}{c}41 / 2 \\
(3-6) \dagger\end{array}$ & $\begin{array}{c}2 \\
(2)\end{array}$ & $\begin{array}{c}2 \\
(2)\end{array}$ & $\begin{array}{c}21 / 2 \\
(2-3)\end{array}$ & $\begin{array}{c}31 / 2 \\
(3-4)\end{array}$ & $\begin{array}{c}4 \\
(3-5)\end{array}$ & $\begin{array}{c}7 \\
(6-8)\end{array}$ & $\begin{array}{c}2 \\
(2)\end{array}$ & $\begin{array}{c}2 \\
(2-3)\end{array}$ \\
\hline 3 and $4 \ldots \ldots$ & $\begin{array}{c}6 \\
(4-7)\end{array}$ & $\begin{array}{c}3 \\
(2-4)\end{array}$ & $\begin{array}{c}4 \\
(3-8)\end{array}$ & $\begin{array}{c}6 \\
(4-8)\end{array}$ & $\begin{array}{c}7 \\
(6-8)\end{array}$ & $\begin{array}{c}8 \\
(6-12)\end{array}$ & $\begin{array}{c}11 \\
(9-13)\end{array}$ & $\begin{array}{c}3 \\
(2-4)\end{array}$ & $\begin{array}{c}5 \\
(3-6)\end{array}$ \\
\hline 5 and $6 \ldots \ldots$ & $\begin{array}{c}10 \\
(5-16)\end{array}$ & $\begin{array}{c}5 \\
(3-8)\end{array}$ & $\begin{array}{c}7 \\
(5-13)\end{array}$ & $\begin{array}{c}8 \\
(5-12)\end{array}$ & $\begin{array}{c}13 \\
(6-18)\end{array}$ & $\begin{array}{c}15 \\
(13-19)\end{array}$ & $\begin{array}{l}\ldots \\
\ldots\end{array}$ & $\begin{array}{c}3 \\
(2-4)\end{array}$ & $\begin{array}{c}5 \\
(3-7)\end{array}$ \\
\hline 7 and 8 . & $\begin{array}{c}11 \\
(9-14)\end{array}$ & $\begin{array}{c}6 \\
(5-7)\end{array}$ & $\begin{array}{c}10 \\
(5-18)\end{array}$ & $\begin{array}{c}11 \\
(10-13)\end{array}$ & $\begin{array}{c}10 \\
(8-11)\end{array}$ & $\begin{array}{l}\ldots \\
\ldots\end{array}$ & $\begin{array}{l}\cdots \\
\cdots\end{array}$ & $\begin{array}{c}5 \\
(3-8)\end{array}$ & $\begin{array}{l}\cdots \\
\cdots\end{array}$ \\
\hline
\end{tabular}

* Distances from pith within which ring count was made for blanks 1 and 2,0 to 3.5 inches; 3 and $4,2.5$ to 5.6 inches; 5 and 6,5 to 7.9 inches; 7 and $8,7.5$ to 10.3 inches.

t Numbers in parentheses represent minimum and maximum ring counts.

had very rapid growth in the material nearest the pith (boxed heart 5 inches square) in the lower part of the trunk. Trees numbered 2 and 5, however, had rapid growth wood appreciably beyond this pith zone, and all specimens of tree number 2 and most of those from tree number 5 were distinctly stronger than the specimens from near the pith that had approximately the same rapid growth rate.

Location in Log. Because the wide-ringed material near the pith appeared to be less dense and weaker than material farther from the pith, a comparison based on several selected properties was made between the specimens located within the $5 \times 5$-inch boxed heart (test specimens numbered 1 and 2 cut adjacent to pith) and all those located outside the boxed heart. These data are presented in table 5 . With the exception of shearing and cleavage strengths, the strength values for the boxed-heart specimens are distinctly lower than for the specimens farther from the pith. This is consistent with studies of other investigators. For example, Markwardt and Wilson (1935) make the statement that, in coniferous species, wood near the pith is often of very rapid growth and low specific gravity. More recently, Larson (1957), 


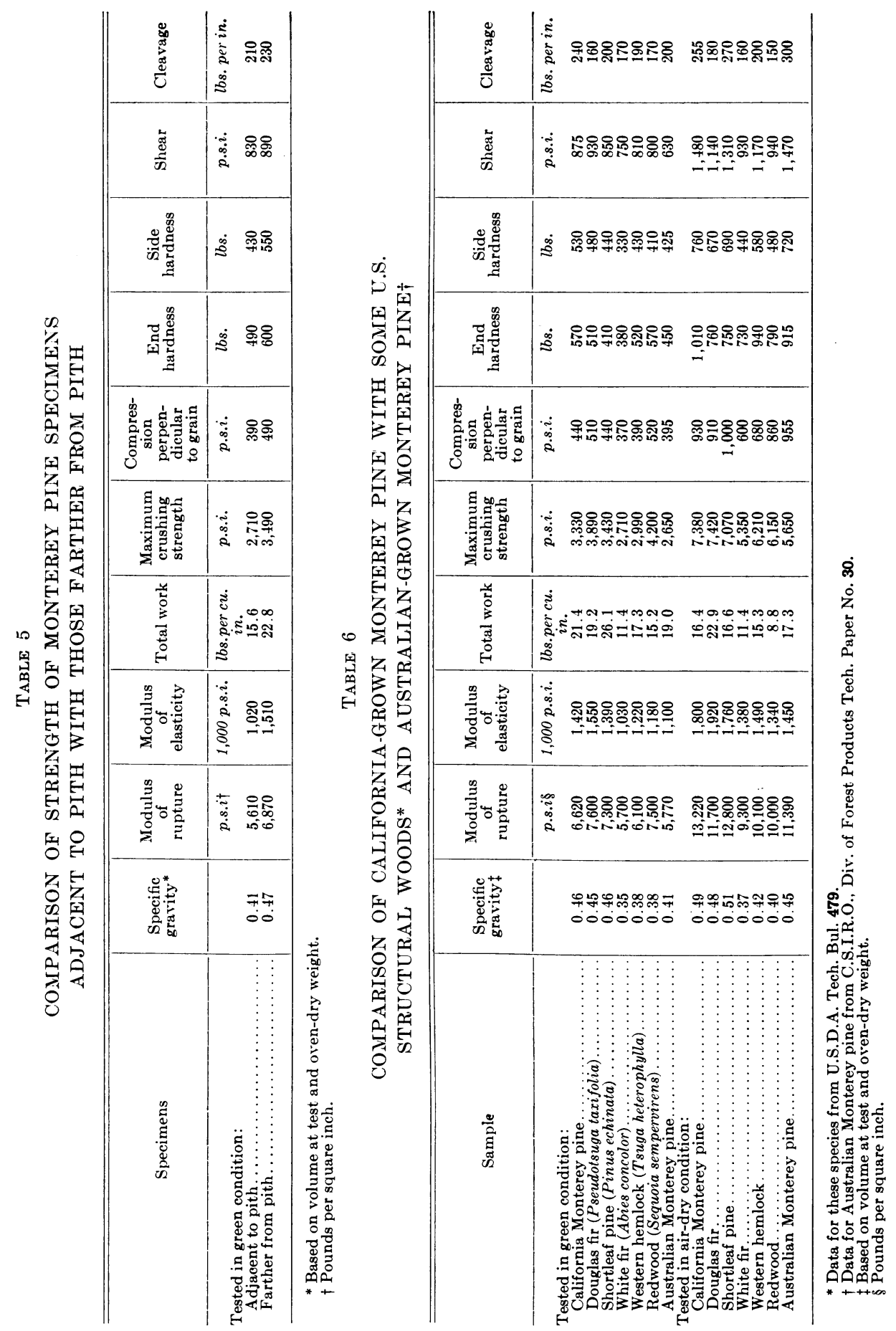




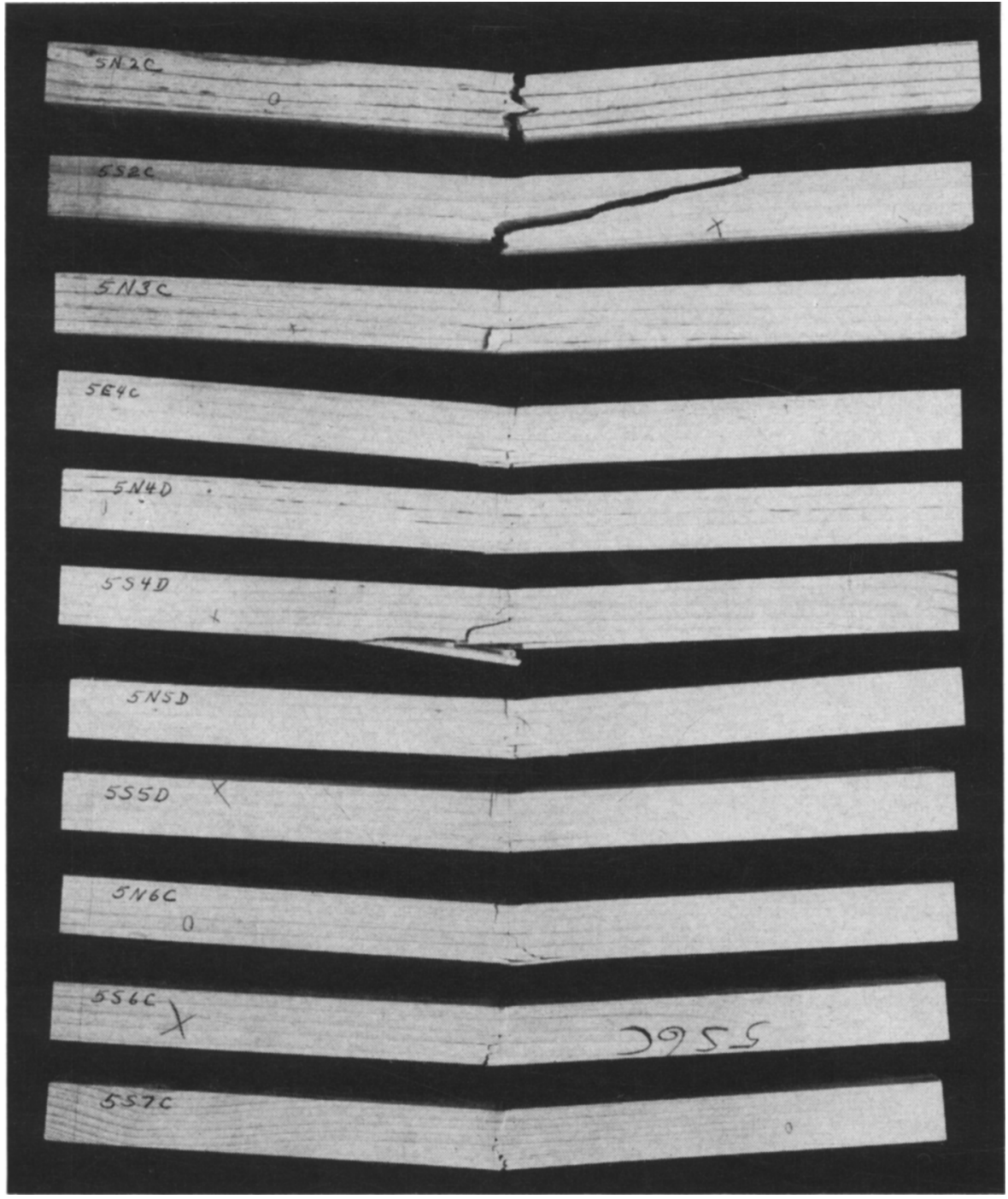

Fig. 2. Samples from tree number 5, tested for static bending at 12 per cent moisture content. 
in a study made on slash pine, concludes that "juvenile wood (up to 6 to 8 years) has been found to be inherently low in summerwood," and, in discussing his results, states that the juvenile wood produces poor quality lumber. He also points out that "rate of growth exerted a negligible influence on both specific gravity and percentage of summerwood and for all practical purposes its effect may be ignored." This same conclusion can be drawn from the high test values of the wide-ringed specimens (trees 2 and 5) outside the boxed heart.

Structural Qualities. Table 6 compares California Monterey pine with some of the structural woods more commonly used in the United States, and with Australian plantation-grown Monterey pine. The data show that California-grown Monterey pine compares very favorably with the structural softwoods commonly used in the United States. In most properties, it resembles both shortleaf and loblolly pine, which is not surprising since the Monterey pine is a hard pine with about the same specific gravity as the other two. As shown in tables 2 and 3, the dried wood, like that of the southern yellow pines, has a lower value for total work than does the green wood, whereas the dried Douglas fir wood (both coast and intermediate types, but not the Rocky Mountain type) shows a slightly higher total work value than the green wood. This suggests that hard pine wood in general tends to be less tough in the dry than in the green condition. The brittle rather than fibrous nature of the tension failure of the air-dry beams is illustrated in figure 2. Langlands (1938), in his study of Australian plantation-grown Monterey pine, reports that although $P$. radiata beams in the air-dry condition are characterized by a sudden "carroty" failure at ultimate load, they rank fairly high among other coniferous woods in ability to withstand shocks and blows. The test values reported in the present study, for impact bending for the four trees from the natural forest (see tables 2 and 3 ), corroborate Langlands' findings with respect to resistance to shock loads. When these values, for both the green and air-dry conditions, are compared with the impact bending values reported by Markwardt and Wilson (1935), they show Monterey pine wood to be distinctly superior to Douglas fir, slightly superior to loblolly and shortleaf pines, and essentially equal to longleaf and slash pines.

The strength values listed in table 6 for the Australian plantation-grown wood resemble very closely the comparable values for the California plantation-grown trees 5 and 6 (see tables 2 and 3), but are distinctly lower than strength values obtained for wood from the mature trees $1,2,3$, and 4 , grown in the natural forest. This agrees with the statement made by Olson et al. (1947), based on a study of six coniferous species that "... with few exceptions, the strength of forest-grown material is higher than that of plantation-grown woods." The writer would add, parenthetically, that the plantation-grown trees on which Olson's study was made were relatively young and small, and that forest-grown and plantation-grown trees of the same age and size might be expected to be essentially identical in their physical properties.

Another interesting comparison can be made between the strength of the boxed-heart specimens of this study (see table 5) and that of the Australian specimens. As might be expected, the strengths are similar since the average speeific gravity of each class of material is identical. This fact explains the lower strength of the smaller and younger plantation-grown trees, since the 
percentage of all the test specimens represented by the material near the pith is greater in these smaller trees than in the larger and older trees grown in the natural forest. These comparisons lead to the belief that the Californiaand Australian-grown Monterey pines produce wood that is similar in properties and that, for comparable density material, the test data and performance record compiled in Australia can be applied to the Californiagrown wood. Further study of a larger sample of California plantationgrown trees is contemplated to test the validity of this belief.

The apparent superiority in strength properties of the old-growth trees over the plantation trees suggested the possibility that there might be a trend showing increasing strength with distance from pith at any given level in the tree. Data for individual tests for all six trees were therefore examined. Disregarding the juvenile wood in the vicinity of the pith, no

TABLE 7

VARIATION OF STRENGTH WITH HEIGHT IN TREE NO. 4

\begin{tabular}{|c|c|c|c|c|c|c|c|c|c|c|}
\hline \multirow{2}{*}{$\begin{array}{c}\text { Height } \\
\text { above ground } \\
\text { of bottom and } \\
\text { top of test log }\end{array}$} & \multicolumn{2}{|c|}{$\begin{array}{l}\text { Specific } \\
\text { gravity }\end{array}$} & \multicolumn{2}{|c|}{$\begin{array}{l}\text { Modulus } \\
\text { of rupture } \\
\text { (p.s.i.)* }\end{array}$} & \multicolumn{2}{|c|}{$\begin{array}{l}\text { Modulus } \\
\text { of elasticity } \\
\text { (1,000 p.s.i.) }\end{array}$} & \multicolumn{2}{|c|}{$\begin{array}{c}\text { Maximum } \\
\text { crushing strength } \\
\text { (p.s.i.) }\end{array}$} & \multicolumn{2}{|c|}{$\begin{array}{l}\text { End hardness } \\
\text { (lbs.) }\end{array}$} \\
\hline & green & air-dry & green & air-dry & green & air-dry & green & air-dry & green & air-dry \\
\hline $\begin{array}{c}\text { ft. } \\
2-11 \ldots \ldots\end{array}$ & 0.56 & 0.58 & 7,270 & 16,740 & 1,600 & 2,290 & 3,790 & 9,200 & 640 & 1,230 \\
\hline $11-20.5 \ldots$ & 0.50 & 0.54 & 7,080 & 15,440 & 1,770 & 2,250 & 3,750 & 9,640 & 610 & 1,170 \\
\hline $33.5-42$. & 0.48 & 0.54 & 6,990 & 14,330 & 1,480 & 1,980 & 3,600 & 9,180 & 590 & 1,040 \\
\hline $58-66.5$. & 0.45 & 0.48 & 6,310 . & 13,860 & 1,480 & 1,930 & 3,140 & 8,530 & 570 & 940 \\
\hline
\end{tabular}

* Pounds per square inch.

evidence of trend was found in trees 1,4 , and 5, but trees 2,3 , and 6 did show a slight tendency toward increase of density and strength outward toward the bark. These results do not differ appreciably from the findings of Langlands (1938) with regard to Australian-grown trees. It is not possible to compare these data closely, however, since Langlands' are based on a series of $5 / 8$-inch-square specimens cut from radial boards, whereas the observations from the present study are based on the distance from the pith of the various $21 / 2 \times 21 / 2$-inch test blanks from all four cardinal directions (fig. 1 , bottom).

To determine if density and strength vary with tree height, data for selected properties from all logs of tree 4 were compared (table 7 ). The data indicate rather consistently that density and strength decrease slightly with increase in height. This is the same trend as that reported by Langlands (1938) for his plantation trees.

Slope of Grain. Excessive slope of grain caused by spiral grain was not a problem in any of the material tested except for a few specimens adjacent to the pith, and even in these, only the material in the first and second rings sloped appreciably. Slopes of grain from 1 inch in 8 to 1 inch in 10 were recorded from several of the number 1 and number 2 specimens on the pith sides, but on the outer side of these same specimens, all slopes of grain measured were straighter than 1 inch in 16 . The only other excessive slope of grain was encountered on the ends of a few test blanks where proximity to knots caused the grain to deviate. In a few instances, such slopes made rejection of the material necessary (note specimens $5 \mathrm{~S} 6 \mathrm{C}$ and $5 \mathrm{~S} 7 \mathrm{C}$ in fig. 2). 
Experience with other Monterey pine trees indicates that the slope of grain has about the same range as that of other commercial softwood species, particularly the southern yellow pines.

Shrinkage. Data on tangential, radial, and volumetric shrinkage are presented in table 8 . They are of about the same general magnitude as those for many other structural softwoods of comparable density. Here again Monterey pine appears to resemble the southern yellow pines in having a some-

TABLE 8

SHRINKAGE PER CENT BASED ON GREEN DIMENSIONS

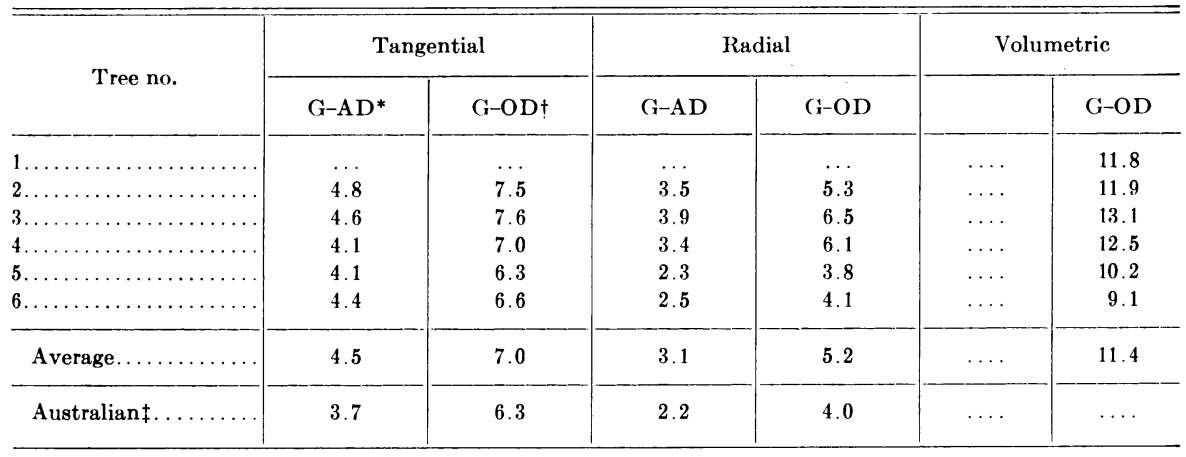

* Green to air-dry dimension.

† Green to oven-dry dimension.

$\ddagger$ Data from C.S.I.R.O., Div. of Forest Products Technical Paper No. 28.

TABLE 9

A COMPARISON OF SPECIFIC GRAVITY AND CERTAIN BENDING PROPERTIES BASED ON TWO 4-TREE SAMPLES OF GREEN NATIVE-GROWN MONTEREY PINE

\begin{tabular}{|c|c|c|c|c|}
\hline Tests & $\begin{array}{l}\text { Specific } \\
\text { gravity }\end{array}$ & $\begin{array}{c}\text { Fiber stress } \\
\text { at } \\
\text { proportional } \\
\text { limit }\end{array}$ & $\begin{array}{l}\text { Modulus } \\
\text { of rupture }\end{array}$ & $\begin{array}{l}\text { Modulus } \\
\text { of elasticity }\end{array}$ \\
\hline & & p.s.i. & p.s.i. & 1,000 p.s.i \\
\hline Mould's*. & 0.49 & 3,660 & 6,980 & 1,487 \\
\hline Cockrell's. & 0.48 & 3,910 & 7,000 & 1,559 \\
\hline
\end{tabular}

* See "Literature Cited."

what lower ratio of tangential to radial shrinkage than do some of the other common softwoods, such as white fir, hemlock, redwood, and spruce. This characteristic makes Monterey pine less likely to warp or distort with moisture-content change. Shrinkage data for Australian-grown material (Div. of Forest Products, 1939; Kelsey and Steele, 1956) indicate that, in this property also, Australian wood performs essentially the same as the native California material.

A study of density and some flexure properties of wood from four trees from the natural Monterey pine forest of California was reported by Moulds (1952). Table 9 shows a comparison of the species means for those four trees and the four from the same forest area used in this study. The closeness of the values strengthens the premise that data from this study are truly representative of native-grown Monterey pine wood. 


\section{SUMMARY}

Average values for several basic mechanical and physical properties of both green and air-dried Monterey pine wood are reported as the result of tests made on six California-grown trees. These values demonstrate that native Monterey pine wood compares favorably in its mechanical properties with several important United States softwoods, especially the southern hard pines. It is also similar in its mechanical properties to Australian-grown Monterey pine wood. The wood of rapid growth near the pith was consistently lighter and weaker than that farther out in the cross-section, and generally had wider growth rings. Other than this weaker central core, there was no consistent general trend of strength with distance out in the crosssection from the pith. There was evidence, however, of a slight diminishing of strength with increasing tree height. Spiral grain was not a serious defect in the material tested except near the pith in a few specimens. The wood had shrinkage properties similar to other softwoods of comparable density.

\section{LITERATURE CITED}

Division of Forest Products

1939. The properties of Australian timbers, Part 3-Pinus radiata D. Don. (Pinus insignis Doug.) Insignis, Monterey, or remarkable pine. C.S.I.R.O., Div. of Forest Products Tech. Paper 28.

Kelsey, K. E., and R. L. SteELe

1956. The shrinkage and density of plantation grown Pinus radiata. C.S.I.R.O., Div. of Forest Products Project T.P. 22, Progress Rpt. 2.

LANGLANDS, I.

1937. Properties of Australian timber, Part 2-Brown mallet (Eucalyptus astringens). C.S.I.R.O., Div. of Forest Products Tech. Paper 23.

1938. The mechanical properties of South Australian plantation-grown Pinus radiata D. Don. C.S.I.R.O., Div. of Forest Products Tech. Paper 30.

LARSON, P. R.

1957. Effect of environment on the percentage of summerwood and specific gravity of slash pine. Yale University School of Forestry Bul. 63.

MARKWARDT, L. J., and T. R. C. Wilson

1935. Strength and related properties of woods grown in the United States. U. S. Dept. of Agr. Tech. Bul. 479.

Moulds, F. R.

1952. Comparative strengths of the timber of California-grown and South Australiangrown Monterey pine (Pinus radiata Don.). Australian Forestry 16(2):100-04.

Olsen, A. R., N. V. Poletika, and H. W. Hicock

1947. Strength properties of plantation-grown coniferous woods. Connecticut Agr. Exp. Sta. Bul. 511. 
The journal Hilgardia is published at irregular intervals in volumes of about 600 pages. The number of issues per volume varies.

Subscriptions are not sold. The periodical is sent as published only to libraries, or to institutions in foreign countries having publications to offer in exchange.

You may obtain a single copy of any issue free, as long as the supply lasts; please request by volume and issue number from:
Agricultural Publications
Room 22, Giannini Hall
University of California
Berkeley 4, California

The limit to nonresidents of California is 10 separate issues on a single order. A list of the issues still available will be sent on request. 